ISSN 1392-3196 / e-ISSN 2335-8947

Zemdirbyste-Agriculture, vol. 101, No. 4 (2014), p. 445-452

DOI 10.13080/z-a.2014.101.057

\title{
Usefulness of MODIS data for assessment of the growth and development of winter oilseed rape
}

\author{
Krzysztof BARTOSZEK \\ University of Life Sciences in Lublin \\ Akademicka 15, 20-950 Lublin, Poland \\ E-mail: krzysztof.bartoszek@up.lublin.pl
}

\begin{abstract}
Satellite remote sensing permits the determination of the state of vegetation of plants simultaneously in distant areas. The paper focuses on the assessment of the usefulness of satellite data retrieved from a moderate resolution imaging spectroradiometer (MODIS) for the determination of the growth and development of winter oilseed rape (Brassica napus L.) in the climatic conditions of Central Europe. The study is based on values of five vegetation indices normalised difference vegetation index, enhanced vegetation index, leaf area index, fraction of photosynthetically active radiation and gross primary production - from the period 2000-2012, as well as results of measurements of rape plant height before winter and after flowering, and the onset of flowering and ripening. Low values of the standard error of the estimate (SEE) were obtained in models in relation to plant height before winter $(\mathrm{SEE}<6 \mathrm{~cm})$ and the onset of flowering ( $\mathrm{SEE}<3$ days). This suggests the possibility of application of vegetation indices from the period preceding measurements and field observations in forecasting of those two characteristics of winter oilseed rape. No statistically significant covariance was found in the case of rape plant height after flowering and the onset of ripening.
\end{abstract}

Key words: Brassica napus, Eastern Poland, growth stages, satellite monitoring, vegetation indices.

\section{Introduction}

Rapeseed has the second largest contribution in the global production of oilseeds. The current dynamic increase in oilseed rape cultivation throughout the world is determined by the growing interest in renewable energy sources. Over the last several years, attempts have been undertaken to reduce the anthropogenic emission of $\mathrm{CO}_{2}$ to the atmosphere (Paustian et al., 1997; Johnson et al., 2007; Vergé et al., 2007). Combustion in diesel engines of biofuel containing fatty acid methyl esters from rape oil results in the emission of $\mathrm{CO}_{2}, \mathrm{CO}$, sulphur compounds, polycyclic aromatic hydrocarbons, and dusts lower than that in the case of traditional diesel oil (Nwafor, 2004; Balat, Balat, 2010). It is presumed that the application of such a bio component can reduce $\mathrm{CO}_{2}$ emission from the transport sector by 113-136 Mt year ${ }^{-1}$ (Peterson, Hustrulid, 1998).

The course of vegetation of rape and the obtained seed crop largely depend on weather conditions (Mendham et al., 1981; Rao, Mendham, 1991; Sidlauskas, Bernotas, 2003). One of the methods of monitoring rape growth and development is remote observation of cultivated fields conducted both from the ground and satellite level. The monitoring applies the phenomenon of reflection of solar radiation, from the visible spectrum or near-infrared, from above-ground parts of plants. The ground-level measurements in experimental fields involve the application of various types of spectrometers. Based on the reflection coefficient values, the so-called vegetation indices are determined, e.g., the normalised difference vegetation index (NDVI), simple ratio (SR), red edge inflection point (REIP) and relative reflectance index (RRI). Applying this method, Piekarczyk et al. (2006) determined that in early autumn, NDVI values were positively correlated with the number of rape plants four weeks after emergence. This constitutes important information on the status of plants at the onset of the vegetation period. Behrens et al. (2006) evidenced that the reflection coefficient of waves with a length of $850 \mathrm{~nm}$ $\left(\mathrm{R}_{850}\right)$ corresponds to the content of fresh and dry mass in the above-ground parts of winter oilseed rape during all of its development stages. Mogensen et al. (1996; 1997) proposed the RRI index which can be helpful in taking decisions on commencing of artificial watering of a plantation, because its values accurately reflect the status of rape plants during soil drought.

Over the last several years, the development of satellite techniques has permitted the use of information on the reflectivity of solar radiation in various wave spectra, allowing for the determination of the photosynthetic activity of plant organs simultaneously over extensive areas. This kind of measurement results were applied among others in the assessment of productivity of rainforests in the western part of the Amazon (Viña, 2012), monitoring of the growth and development dynamics of forests in north-eastern Australia (Bhandari et al., 2011), the extent of desertification in Kenya (He et al., 2013), and changes in net primary production in south-eastern China (Peng et al., 2010). In relation to cultivated plants, data provided by a moderate resolution imaging spectroradiometer (MODIS) were used among 
others in the estimation of wheat yield in south Italy (Maselli et al., 2011), potato yield in the Munshiganj area in Bangladesh (Bala, Islam, 2009), corn yield in Indiana State in the USA (Fang et al., 2010), and monitoring of soybean cultivation in south Brazil (Rizzi et al., 2006), as well as rice in south China (Xiao et al., 2005).

The limitations of the satellite method as compared to the earth-bound method include lower temporal resolution of data, and effect of cloudiness on the obtained vegetation indices (Motohka et al., 2011; Park, 2013). A definite advantage is free on-line access to MODIS data bases, largely increasing the number of persons and institutions able to monitor the state of plant vegetation in extensive areas on their own account. In the case of winter oilseed rape, studies confirming the usefulness of MODIS data for the assessment of the growth and development of this important industrial plant are insufficient.

The primary objective of this paper is the assessment of the possibilities of application of satellite remote sensing in monitoring of the vegetation of winter oilseed rape under varying climatic conditions.

\section{Materials and methods}

The paper is based on the data from the field research conducted at two experimental stations located in East Poland and belonging to the Research Centre for Cultivar Testing (COBORU). One of them is located in Bezek $\left(51^{\circ} 10^{\prime} \mathrm{N}, 23^{\circ} 16^{\prime} \mathrm{E}, 224 \mathrm{~m}\right.$ a.s.l.), and the other - in Cicibór Duży $\left(52^{\circ} 04^{\prime} \mathrm{N}, 23^{\circ} 06^{\prime} \mathrm{E}, 143 \mathrm{~m}\right.$ a.s.1.). The distance between the two measurement points is approximately $120 \mathrm{~km}$. The results of measurements and observations of winter oilseed rape (Brassica napus L.) plants were obtained following the methodology determined by COBORU, and covered the period from 2000 to 2012. The field experiments were conducted at standard level of agricultural technology. In Cicibór Duży, the research was performed on Podzol (PZ) developed from loamy sand, and in Bezek, on Rendzina developed from chalk rock. The population and hybrid varieties of rape registered by COBORU and maintained in production for at least several years were selected for the study.

The averaged data for all of the analysed varieties covered biometric measurements (rape plant height before winter and after flowering), as well as the onset of flowering and the onset of ripening. The measurements of plant height before winter were performed in the initial period of the inhibition of vegetation in autumn. The height of rosettes was measured at five sites in a field, and the mean result was calculated. Height of plants after flowering was the distance from the ground level to the top of straightened cultivated plants along the measuring instrument. The measurement was performed at three randomly selected sites in a field, and the result was the average from the performed measurements. The onset of flowering of rape was determined as the date of flowering of approximately $10 \%$ of plants of a given variety in a field. The end of flowering was recorded when all flowers in more than $90 \%$ of plants faded. The date of ripening was defined as the date when rape stems were light green, siliques yellowish, and seeds completely brown. The values concerning the analysed characteristics of rape in the study period showed clear correlation between the two experimental stations (Table 1).
Table 1. Characteristics of the growth and development of winter oilseed rape from 2000 to 2012, and relationship between the two experimental stations

\begin{tabular}{|c|c|c|c|c|c|}
\hline Character & $\begin{array}{l}\text { Experi- } \\
\text { mental } \\
\text { station }\end{array}$ & $\begin{array}{l}\text { Mean } \\
\text { values }\end{array}$ & $\begin{array}{l}\text { Maxi- } \\
\text { mum } \\
\text { (year) }\end{array}$ & $\begin{array}{l}\text { Mini- } \\
\text { mum } \\
\text { (year) }\end{array}$ & $r$ \\
\hline \multirow{2}{*}{$\begin{array}{l}\text { Plant height } \\
\text { before winter } \\
\text { (HBW) }\end{array}$} & Bezek & $20.8 \mathrm{~cm}$ & $\begin{array}{c}42.0 \mathrm{~cm} \\
(2006)\end{array}$ & $\begin{array}{l}8.6 \mathrm{~cm} \\
(2002)\end{array}$ & \multirow{2}{*}{$0.93 * *$} \\
\hline & $\begin{array}{l}\text { Cicibór } \\
\text { Duży }\end{array}$ & $19.1 \mathrm{~cm}$ & $\begin{array}{c}35.2 \mathrm{~cm} \\
(2006)\end{array}$ & $\begin{array}{l}8.0 \mathrm{~cm} \\
(2002)\end{array}$ & \\
\hline \multirow{2}{*}{$\begin{array}{l}\text { Plant height } \\
\text { after } \\
\text { flowering } \\
\text { (HAF) }\end{array}$} & Bezek & $147.6 \mathrm{~cm}$ & $\begin{array}{c}180.1 \mathrm{~cm} \\
(2008)\end{array}$ & $\begin{array}{c}115.9 \mathrm{~cm} \\
(2006)\end{array}$ & \multirow{2}{*}{$0.62 *$} \\
\hline & $\begin{array}{c}\text { Cicibór } \\
\text { Duży }\end{array}$ & $151.7 \mathrm{~cm}$ & $\begin{array}{c}191.8 \mathrm{~cm} \\
(2008) \\
\end{array}$ & $\begin{array}{c}102.4 \mathrm{~cm} \\
(2006)\end{array}$ & \\
\hline \multirow{2}{*}{$\begin{array}{l}\text { Onset of } \\
\text { Flowering } \\
\text { (OF) }\end{array}$} & Bezek & 4 May & $\begin{array}{l}\text { 12 May } \\
(2006)\end{array}$ & $\begin{array}{c}\text { 26 April } \\
\text { (2007) }\end{array}$ & \multirow[b]{2}{*}{$0.94 * *$} \\
\hline & $\begin{array}{l}\text { Cicibór } \\
\text { Duży }\end{array}$ & 4 May & $\begin{array}{l}14 \text { May } \\
(2006)\end{array}$ & $\begin{array}{l}28 \text { April } \\
\text { (2007) }\end{array}$ & \\
\hline \multirow{2}{*}{$\begin{array}{l}\text { Onset of } \\
\text { ripening } \\
\text { (OR) }\end{array}$} & Bezek & 7 July & $\begin{array}{l}\text { 15 July } \\
(2006)\end{array}$ & $\begin{array}{l}25 \text { June } \\
(2002)\end{array}$ & \multirow{2}{*}{$0.64 *$} \\
\hline & $\begin{array}{l}\text { Cicibór } \\
\text { Duży }\end{array}$ & 10 July & $\begin{array}{l}19 \text { July } \\
\text { (2006) }\end{array}$ & $\begin{array}{l}28 \text { June } \\
(2002)\end{array}$ & \\
\hline
\end{tabular}

A time series of MODIS Terra normalised difference vegetation index (NDVI) and enhanced vegetation index (EVI) 16-day composite 250-m (MOD13Q1), MODIS Terra leaf area index (LAI) and fraction of photosynthetically active radiation (fPAR) 8-day composite 1000-m (MOD15A2), and MODIS Terra gross primary production (GPP collection 5.1) 8-day composite 1000-m(MOD17A2_51) data were downloaded from the National Aeronautic and Space Administration (NASA) Land Process Distributed Active Archive Center (LPDAAC) for the study area for the period from March through October from 2000 to 2012. In order to obtain the most credible data, pixels located possibly closest to the experimental fields were selected. Moreover, for comparative purposes, values of all of the indices were standardised and converted to 16-day composite periods. The day of year for each MODIS data set represents the first day of the period of the 16-day composite.

The analysis of air temperature and precipitation conditions in the study area was performed based on the data from meteorological stations located in the vicinity of the experimental fields. The standardised precipitation index (SPI) was calculated based on monthly precipitation totals (McKee et al., 1993).

The Shapiro-Wilk test was used to assess the normality of distribution of all variables. There was no reason to reject the hypothesis of normality, so linear correlation and regression was applied to explain the relationship between the analyzed data. The statistical significance of correlation coefficients was tested by the Student $t$-test at $\alpha=0.05$ and $\alpha=0.01$. In turn, Jackknife method was used to validate regression models. It is a nonparametric and specific resampling technique whose purpose is to estimate, inter alia, the standard errors of regression model parameters (Sahinler, Topuz, 2007). On the basis of this method, the accuracy of the models was determined by means of the determination coefficient $\left(R^{2}\right)$, the standard error of the estimate (SEE) and the variance of standard error of the estimate (VarSEE). Statistical analyses were performed by software Statistica 9.1 . 


\section{Results and discussion}

Climatic conditions. In East Poland, the study years were distinguished by varied temperature conditions in individual seasons. In winter, cases of significant, both positive and negative deviations of the mean air temperature values occurred (Fig. $1 \mathrm{~A}$ ). In the remaining seasons, and particularly in summer, warmer
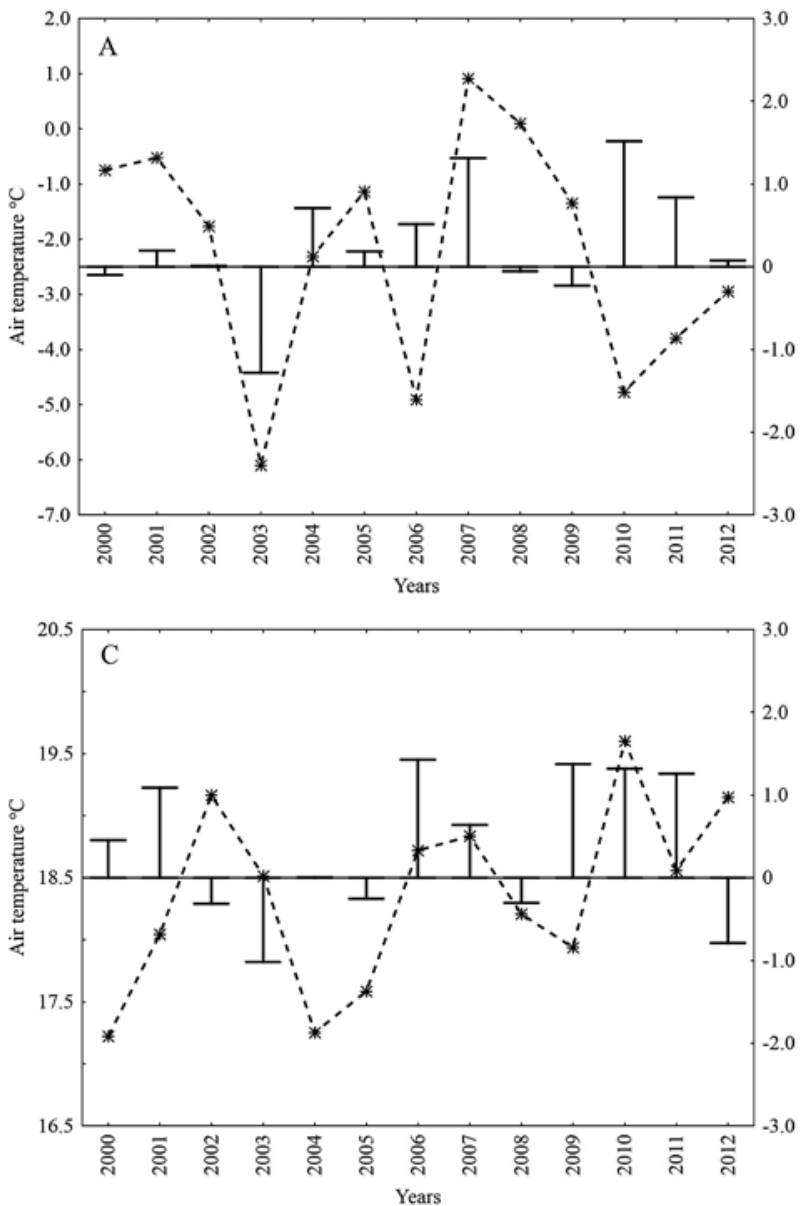

periods occurred more frequently than on the average in the multiannual 1981-2010. Based on the calculated SPI values, a generally low number of cases of occurrence of strong meteorological drought were determined. In the period 2000-2012, precipitation totals lower than the norm were the most frequently recorded in autumn, and the most seldom in winter and summer (Fig. 1 A-D).
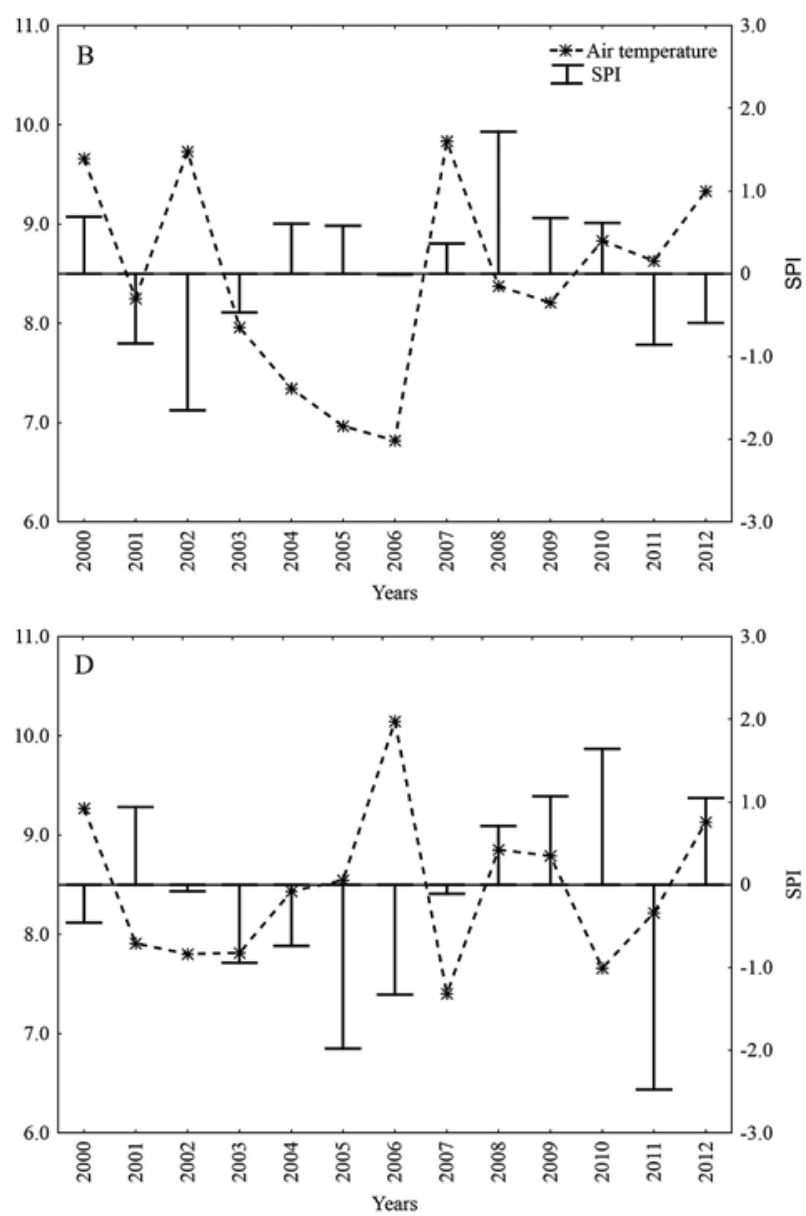

Figure 1. Temporal variability of the mean value of air temperature and standardised precipitation index (SPI) in winter (A), spring (B), summer (C) and autumn (D) in the analyzed area from 2000 to 2012

At both experimental stations, the highest rape plant height before winter was observed in 2006, when extremely warm autumn occurred (Table 1, Fig. 2 D) along with high precipitation totals in August. In 2002, when the plant height was low, August was distinguished by the occurrence of shortage of precipitation and a high number of hot days $\left(t_{\max }>25^{\circ} \mathrm{C}\right)$. These findings confirm earlier studies by among others Rao and Dao (1987), Lamb and Johnson (2004) and Russo et al. (2010). The authors correlated delayed and uneven germination of rape seeds with a decrease in soil humidity and high air temperature during and right after the sowing period. Maximum percent germination was markedly lower with decrease in soil water potential from -250 to $-500 \mathrm{kPa}$ and when air temperature was above $32^{\circ} \mathrm{C}$. According to the authors, such conditions considerably affect the growth dynamics of the plant in the autumn season. A delayed onset of development stages in spring occurred after cold and snowy winters in 2003 and 2006, and a particularly early one in 2007 - after abnormally warm winter (Table 1, Fig. 2 A). Furthermore, very early ripening was observed in 2002 after very warm and dry spring (Table 1, Fig. 2 B).
Annual variability of vegetation indices. From March to October, the course of vegetation indices standardised and averaged for the years 2000-2012 was similar at both experimental stations (Fig. 2 A and C). The highest values occurred in the period from late May to the second ten-day period of June (146-162 days of year). This means that at that time, plant organs reached the maximum photosynthetic activity, and were distinguished by the optimal development over the year. For example, during the time, NDVI values varied between 0.61 (2003) and 0.84 (2002), and LAI values between 0.50 (2006) and 3.35 (2007). The decrease in the values in the consecutive weeks could result from rape ripening (decreasing content of chlorophyll in the over-ground parts of plants), and then changes in the soil coverage (plant harvesting). The discontinued decrease in the values of the majority of vegetation indices at the turn of summer and autumn (242-274 days of year) could be related to the beginning of the vegetation of winter cereals. Only GPP values showed a continued decrease from the abovementioned maximum (146-162 days of year) to early November (306 day of year). 

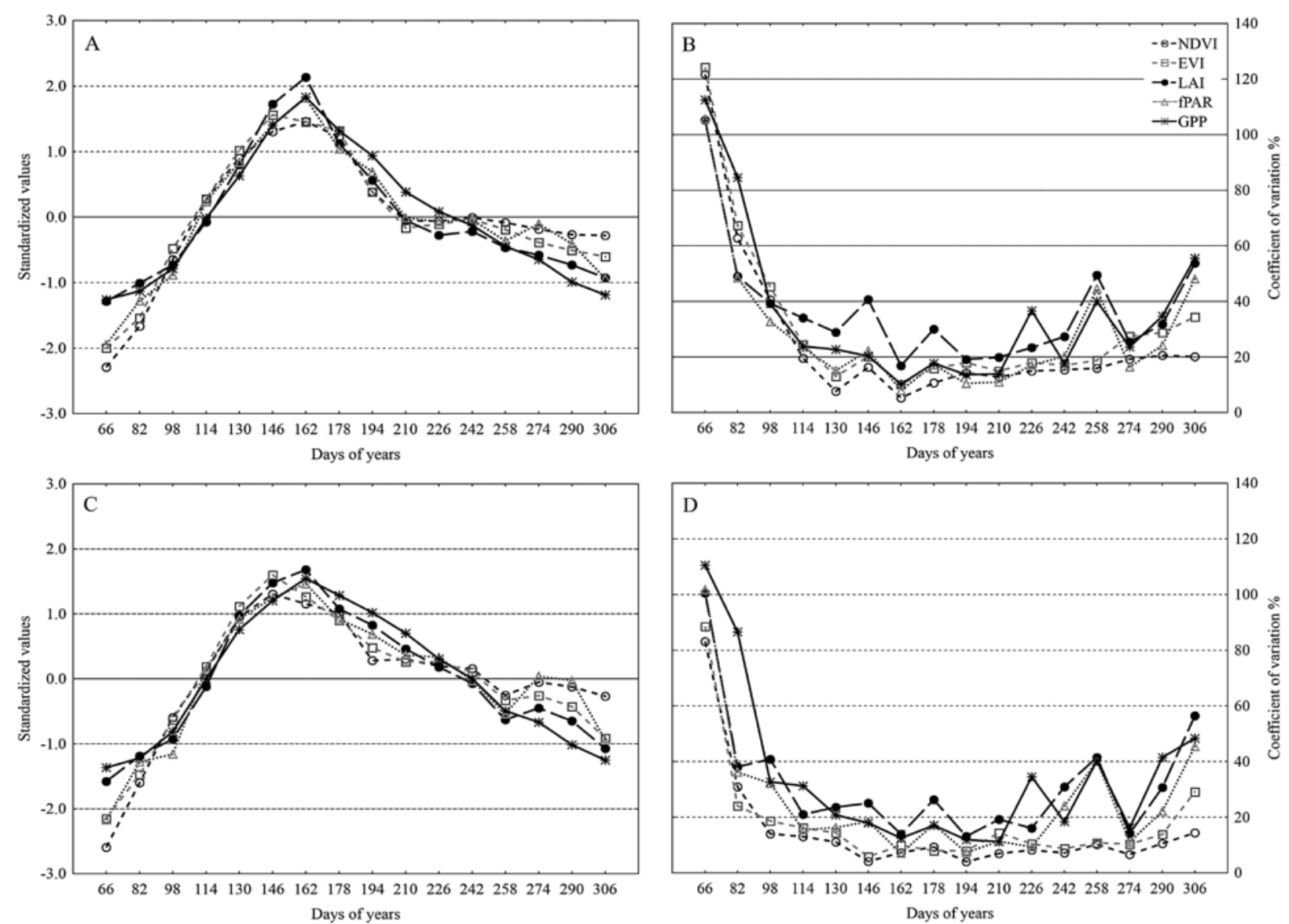

NDVI - normalised difference vegetation index, EVI - enhanced vegetation index, LAI - leaf area index, fPAR - fraction of photosynthetically active radiation, GPP - gross primary production

Figure 2. Temporal variability of the mean standardised values of vegetation indices and the coefficient of variation in Bezek (A and B) and Cicibór Duży (C and D) at the days of year

Another characteristic of the vegetation indices was a very high variability of their values in March and early April (66-98 days of year) in relation to individual years (Fig. 2 B and D). This is accounted for by the typical of the moderate climate cyclical occurrence of very early or very late end of thermal winter. For example, the state of vegetation of plants in East Poland in March 2003 and 2006 corresponded to the index values approximate to zero. This resulted from not only negative air temperature (low photosynthetic activity of plant organs), but also long-lasting snow cover. Considerably lower values of the coefficient of variation occurred in the period from late April to late September, with the minimum in June and July (162-210 days of year). A slight increase in the coefficient of variation in August (from 226 day of year) could be related to the date of plant harvesting differing in individual years, and various rate of growth and development of winter crops in autumn (Fig. 2 B and D). In the years 2000-2012, at both experimental stations, the highest values of the coefficient of variation distinguished LAI and GPP, and the lowest NDVI and EVI.

Plant height before winter. The height of rape plants measured before the inhibition of vegetation showed statistically significant covariance with the values of the analysed vegetation indices from late September to middle October (274-290 days of year) (Fig. 3 A).

Lower correlation coefficient values in late October (306 day of year) were presumably related to a decrease in the duration of days and decreasing air temperature values, affecting the photosynthetic activity of plant organs. In the case of LAI and GPP, this could also result from the performance in certain years of agrotechnical measures aimed at the reduction of the density of rape plants before the winter season. The linear regression models largely permitted the assessment of rape plant height before winter based on the vegetation index values from late September (274 day of year) (Table 2). The most accurately determined characteristic was described by EVI, LAI, and fPAR. The standard error values suggested the need for finding other independent variables to permit even better adjustment of the model.

According to Pospišil et al. (2011), the occurrence of droughts in late summer does not favour uniform emergence of winter oilseed rape. The authors suggest that lower sum of precipitation $(<70 \mathrm{~mm})$ in Croatia from August to September has also an adverse effect on obtaining a dense and uniform plantation. In relation to such conclusions, the covariance between the values of meteorological elements from those two months and the discussed characteristic was assessed. The study showed that rape plants were shorter than the average height before winter, when lower relative air humidity values $\left(R^{2}=0.62\right)$, lower precipitation totals $\left(R^{2}=0.67\right)$, and higher air temperature $\left(R^{2}=0.42\right)$ were recorded in August (sowing period). In the obtained multiple regression models, apart from the vegetation indices, the independent variables were SPI values from August (Table 3). SEE and VarSEE values were considerably lower than in the previous models (Table 2). Therefore, based on EVI and LAI values from late September, rape plant height before winter could be forecasted with lower error. 

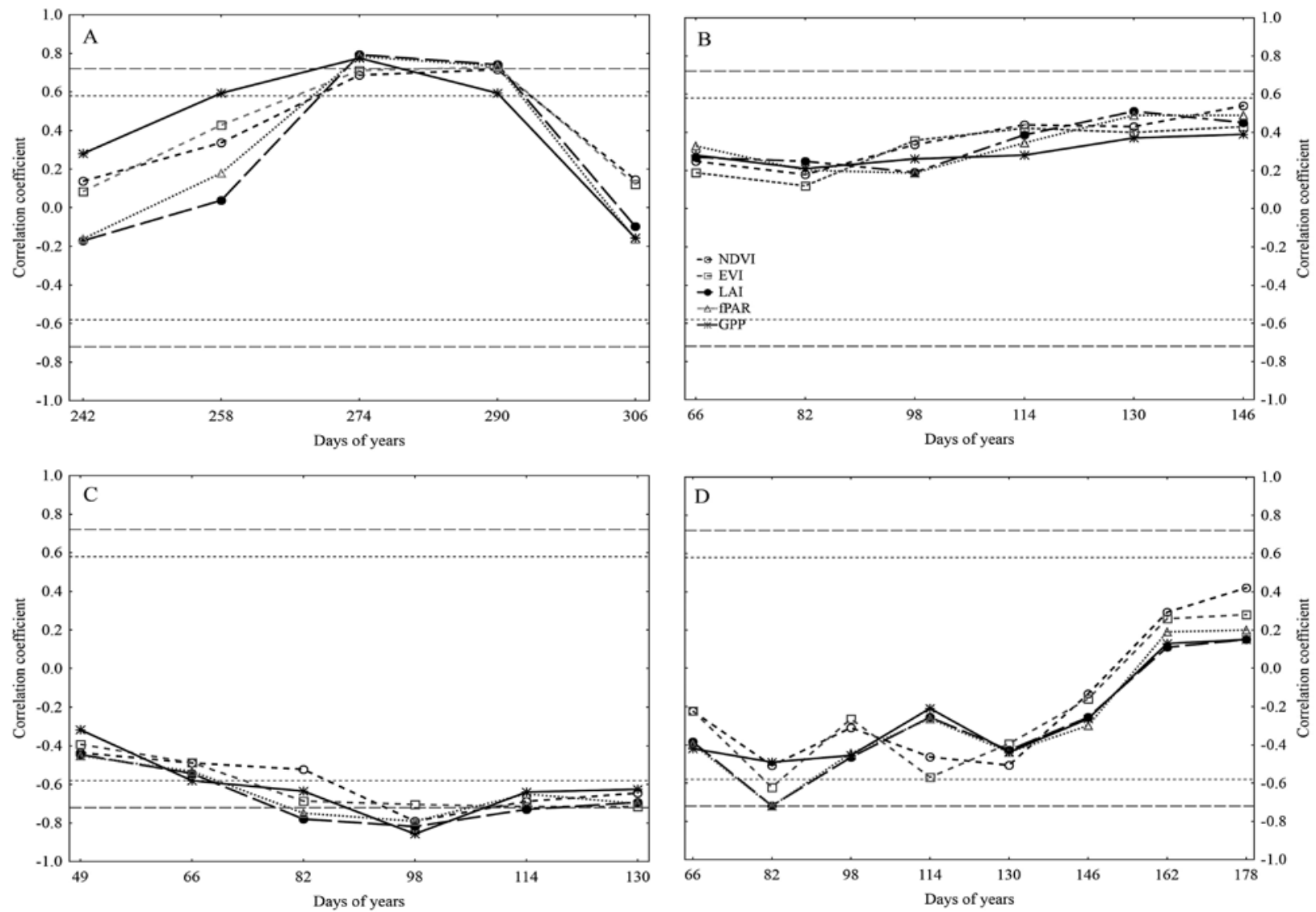

Notes. Horizontal dashed lines indicate correlations significant at a $p$-value of $<0.01$; horizontal dotted lines at a $p$-value of $<0.05$. NDVI - normalised difference vegetation index, EVI - enhanced vegetation index, LAI - leaf area index, fPAR - fraction of photosynthetically active radiation, GPP - gross primary production.

Figure 3. Temporal variability of correlation coefficients between values of vegetation indices and plant height before winter (A), plant height after flowering (B), the onset of flowering (C), and the onset of ripening (D) in the analyzed area

Table 2. Relationships between the four characteristics of the winter rapeseed and vegetation indices for various days of year retrieved from MODIS products

\begin{tabular}{|c|c|c|c|c|c|}
\hline Character & $\begin{array}{c}\text { Day of year } \\
\text { (date) }\end{array}$ & Model equation & $R^{2}$ & SEE & VarSEE \\
\hline \multirow{5}{*}{ Plant height before winter (HBW) } & \multirow{5}{*}{$\begin{array}{c}274 \\
\left(30^{\text {th }} \text { September }\right)\end{array}$} & $\mathrm{HBW}=67.14 \times \mathrm{NDVI}-15.78$ & 0.41 & 6.26 & 1.40 \\
\hline & & $\mathrm{HBW}=98.99 \times \mathrm{EVI}-10.92$ & 0.56 & 5.43 & 0.71 \\
\hline & & $\mathrm{HBW}=43.31 \times \mathrm{LAI}-5.12$ & 0.54 & 5.53 & 1.32 \\
\hline & & $\mathrm{HBW}=81.25 \times \mathrm{fPAR}-12.18$ & 0.55 & 5.49 & 0.99 \\
\hline & & $\mathrm{HBW}=1823.77 \times \mathrm{GPP}-1.09$ & 0.46 & 5.98 & 0.52 \\
\hline \multirow{5}{*}{ Plant height after flowering (HAF) } & \multirow{5}{*}{$\begin{array}{c}146 \\
\left(25^{\text {th }} \text { May }\right)\end{array}$} & $\mathrm{HAF}=114.95 \times \mathrm{NDVI}+65.17$ & 0.25 & 18.47 & 8.11 \\
\hline & & $\mathrm{HAF}=97.22 \times \mathrm{EVI}+96.36$ & 0.15 & 19.67 & 10.39 \\
\hline & & $\mathrm{HAF}=10.16 \times \mathrm{LAI}+130.39$ & 0.16 & 19.58 & 9.17 \\
\hline & & $\mathrm{HAF}=68.27 \times \mathrm{fPAR}+107.43$ & 0.21 & 18.99 & 7.40 \\
\hline & & $\mathrm{HAF}=583.81 \times \mathrm{GPP}+120.01$ & 0.09 & 20.42 & 9.56 \\
\hline \multirow{5}{*}{ Onset of flowering (OF) } & \multirow{5}{*}{$\begin{array}{c}98 \\
\text { ( } 7^{\text {th }} \text { April) }\end{array}$} & $\mathrm{OF}=-29.39 \times \mathrm{NDVI}+139.08$ & 0.54 & 2.85 & 0.24 \\
\hline & & $\mathrm{OF}=-32.01 \times \mathrm{EVI}+134.52$ & 0.46 & 3.07 & 0.46 \\
\hline & & $\mathrm{OF}=-17.63 \times \mathrm{LAI}+134.48$ & 0.61 & 2.62 & 0.25 \\
\hline & & $\mathrm{OF}=-40.25 \times \mathrm{fPAR}+137.58$ & 0.60 & 2.63 & 0.25 \\
\hline & & $\mathrm{OF}=-964.84 \times \mathrm{GPP}+137.01$ & 0.65 & 2.46 & 0.20 \\
\hline \multirow{5}{*}{ Onset of ripening (OR) } & \multirow{5}{*}{$\begin{array}{c}178 \\
\left(26^{\text {th }} \text { June }\right)\end{array}$} & $\mathrm{OR}=37.70 \times \mathrm{NDVI}+164.46$ & 0.17 & 6.03 & 0.88 \\
\hline & & $\mathrm{OR}=22.09 \times \mathrm{EVI}+180.21$ & 0.06 & 6.43 & 0.75 \\
\hline & & $\mathrm{OR}=1.22 \times \mathrm{LAI}+189.18$ & 0.01 & 6.60 & 0.78 \\
\hline & & $\mathrm{OR}=10.88 \times \mathrm{fPAR}+184.89$ & 0.03 & 6.53 & 0.77 \\
\hline & & $\mathrm{OR}=49.17 \times \mathrm{GPP}+188.71$ & 0.00 & 6.61 & 0.84 \\
\hline
\end{tabular}

NDVI - normalised difference vegetation index, EVI - enhanced vegetation index, LAI - leaf area index, fPAR - fraction of photosynthetically active radiation, GPP - gross primary production; $R^{2}$ - determination coefficient, SSE - standard error of the estimate, VarSEE - variance of standard error of the estimate 
Table 3. Relationships between the rapeseed plant height before winter (HBW), values of standardised precipitation index (SPI) in August and vegetation indices on $30^{\text {th }}$ September retrieved from MODIS products

\begin{tabular}{clccc}
\hline Vegetation index & \multicolumn{1}{c}{ Model equation } & $R^{2}$ & SEE & VarSEE \\
\hline NDVI & $\mathrm{HBW}=25.18 \times \mathrm{NDVI}+5.15 \times \mathrm{SPI}_{\text {Aug }}+5.08$ & 0.77 & 4.02 & 0.50 \\
EVI & $\mathrm{HBW}=49.37 \times \mathrm{EVI}+4.54 \times \mathrm{SPI}_{\text {Aug }}+3.29$ & 0.82 & 3.56 & 0.40 \\
LAI & $\mathrm{HBW}=22.43 \times \mathrm{LAI}+4.61 \times \mathrm{SPI}_{\text {Aug }}+5.69$ & 0.83 & 3.46 & 0.27 \\
fPAR & $\mathrm{HBW}=37.77 \times \mathrm{fPAR}+4.59 \times \mathrm{SPI}_{\text {Aug }}+3.72$ & 0.80 & 3.73 & 0.34 \\
$\mathrm{GPP}$ & $\mathrm{HBW}=701.03 \times \mathrm{fPAR}+4.98 \times \mathrm{SPI}_{\text {Aug }}+10.44$ & 0.77 & 3.99 & 0.43 \\
\hline
\end{tabular}

NDVI - normalised difference vegetation index, EVI - enhanced vegetation index, LAI - leaf area index, fPAR - fraction of photosynthetically active radiation, GPP - gross primary production; $R^{2}$ - determination coefficient, SSE - standard error of the estimate, VarSEE - variance of standard error of the estimate

A clear maximum of the standardised vegetation index values from late September occurred in 2006, which also corresponded with high rape plant height before winter (Fig. 4 A). Much lower index values were recorded in late September 2002 and 2003 - the height of rape in the period of inhibition of vegetation amounted to only approximately $10 \mathrm{~cm}$.

Plant height after flowering. The vegetation index values from the period from early March to middle May (66-130 days of year) accounted for the height of rape plants after the flowering stage to a low degree (Fig. $3 \mathrm{~B}$ ). The highest correlation coefficient values were recorded in late May (146 day of year), i.e. in the period of performing measurements of the height of rape plants. High SEE values showed the inability to apply satellite
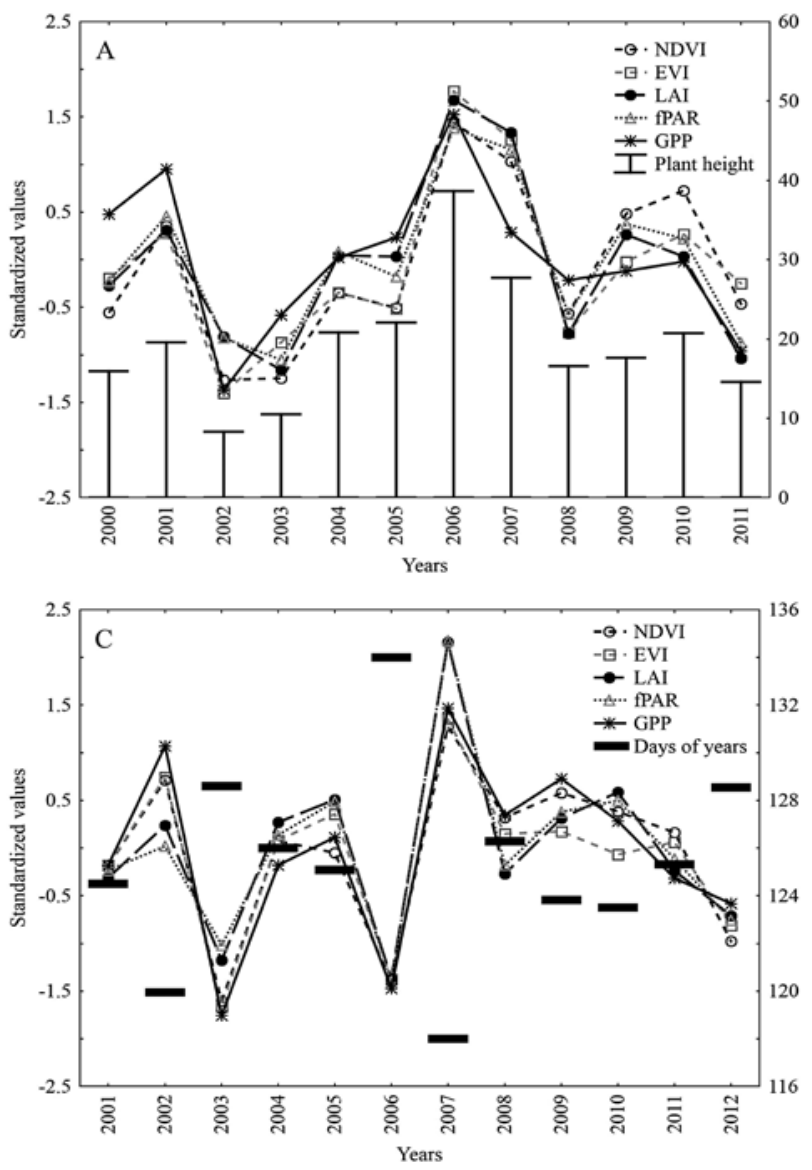

data to monitor the characteristic (Table 2). In the course of vegetation index values measured in late May (146 day of year), the identifiable minimum occurred in 2006 (Fig. 4 B). In that year very cold winter was followed by very cold spring. In the years analysed, the rape plant height after flowering was lower when air temperature values from January to March were below the average $\left(R^{2}=0.64\right)$. This type of thermal conditions undoubtedly contributed to the low rate of growth and development of rape plants in the spring season 2006, as confirmed by vegetation index values.

The onset of flowering. The satellite data from late March and early April (82-98 days of year) showed a statistically significant covariance with the onset of flowering of rape (Fig. $3 \mathrm{C}$ ). Based on the vegetation
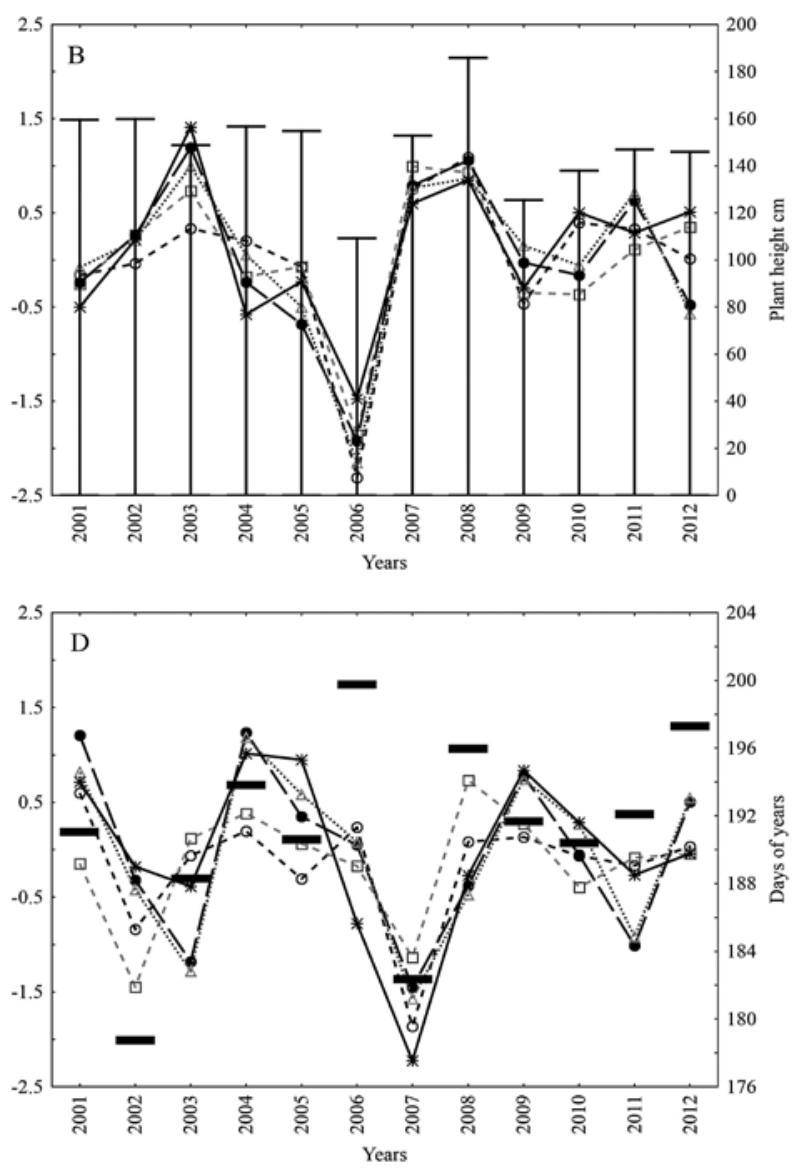

NDVI - normalised difference vegetation index, EVI - enhanced vegetation index, LAI - leaf area index, fPAR - fraction of photosynthetically active radiation, GPP - gross primary production

Figure 4. Temporal variability of plant height before winter (A), plant height after flowering (B), the onset of flowering (C), the onset of ripening (D), and standardised values of vegetation indices from a specific day $(274,146,98$ and 178 , respectively) of the year 
index values from early April (98 day year), the onset of the analysed phenophase could be forecasted with low error (Table 2). The onset of flowering was affected by the thermal conditions of winter $\left(R^{2}=0.49\right)$ and spring $\left(R^{2}=\right.$ $0.65)$. The course of vegetation index values showed that after very cold winters in the study area (2003 and 2006), the development of rape plants was largely delayed (low index values), which resulted in a delay in the onset of the phenophase (Fig. 4 C). Extremely warm winter and spring 2007 favoured early vegetation, and therefore the occurrence of considerable photosynthetic activity of plant organs already in early April, and flowering of rape in the third ten-day period of the month.

The onset of ripening. In the case of the onset of ripening in the period from March to May (66-130 days of year), a lower covariance was determined in comparison to the previously discussed development stage (Fig. 3 D). Therefore, vegetation indices were not good predictors for the relative variable. Dates were negatively correlated with vegetation index values from the period. Therefore, the condition of rape plants after winter could affect the onset of ripening of seeds. However, in comparison to the onset of flowering, the thermal conditions of winter and spring were of less important for the onset of the phenophase ( $R^{2}$ of 0.38 and 0.52 , respectively). Interestingly, from early June (162 day of year), the correlation coefficient became positive (Fig. 3 D). It was observed that in years with the onset of ripening of seeds earlier than the average, simultaneously considerably lower vegetation index values were recorded in June. In this case, the photosynthesis intensity and lower chlorophyll content in different organs could be of importance (in the final period of rape vegetation, the siliques become yellow). The vegetation index values from late June (178 day of year) accounted for the variability of the onset of ripening to a low degree (Table 2). Moreover, in the period 2001-2012, considerable differences were determined in the course of their values (Fig. 4 D). In the final stage of development of rape, the coefficients of correlation between NDVI and EVI and LAI, fPAR, and GPP were statistically insignificant.

\section{Conclusions}

1. The linear regression models that define the relationship between vegetation indices and the plant height before winter and the onset of flowering were distinguished by high value of the coefficient of determination, and low standard error of the estimate. This suggests the possibility of forecasting of the discussed characteristics of winter oilseed rape. It was also evidenced that this type of forecast is not possible in relation to the rape plant height after flowering and the onset of ripening.

2. Vegetation index values accurately reflected the state of development of the plants in relation to weather conditions in the period preceding measurements in the experimental fields. Weak condition of plants in autumn was observed after hot and dry August, and in the spring season after long and cold winter. High vegetation index values in May and June were recorded in years with very warm winter and spring. Rape plant height before winter was best described by standardised precipitation index (SPI) values from August and vegetation index values from late September.

3. Satellite data can supplement study results obtained by means of field spectroscopy, undoubtedly distinguished by higher precision of (in situ) measurements. In the case of the general assessment of the state of vegetation of winter oilseed rape over a larger area, satellite remote sensing can constitute the only credible source of information.

\section{Acknowledgements}

The paper was prepared in the scope of the research project of the Polish Ministry of Science and Higher Education No. N N310 448738 implemented in the years 2010-2011.

Received 24112013

Accepted 20082014

\section{References}

Bala S. K., Islam A. S. 2009. Correlation between potato yield and MODIS derived vegetation indices. International Journal of Remote Sensing. 30 (10): 2491-2507 http://dx.doi.org/10.1080/01431160802552744

Balat M., Balat H. 2010. Progress in biodiesel processing. Applied Energy. 87 (6): 1815-1835 http://dx.doi.org/10.1016/j.apenergy.2010.01.012

Behrens T., Müller J., Diepenbrock W. 2006. Utilization of canopy reflectance to predict properties of oilseed rape (Brassica napus L.) and barley (Hordeum vulgare L.) during ontogenesis. European Journal of Agronomy, 25 (4): 345-355 http://dx.doi.org/10.1016/j.eja.2006.06.010

Bhandari S., Phinn S., Gill T. 2011. Assessing viewing and illumination geometry effects on the MODIS vegetation index (MOD13Q1) time series: implications for monitoring phenology and disturbances in forest communities in Queensland, Australia. International Journal of Remote Sensing. 32 (22): 7513-7538 http://dx.doi.org/10.1080/01431161.2010.524675

Fang H., Liang S., Gerrit H. 2010. Integration of MODIS LAI and vegetation index products with the CSM-CERESMaize model for corn yield estimation. International Journal of Remote Sensing. 32 (4): 1039-1065 http://dx.doi.org/10.1080/01431160903505310

He L., Wang C., Bie Q., Zhao C.-Y. 2013. Monitoring of desertification dynamic in Kenya during 2001-2010 using MOD13Q1 data. Journal of Desert Research, 33 (1): 4652 (in Chinese)

Johnson J.M. F., FranzluebbersA. J., Weyers S.L., Reicosky D. C. 2007. Agricultural opportunities to mitigate greenhouse gas emissions. Environmental Pollution, 150 (1): 107-124 http://dx.doi.org/10.1016/j.envpol.2007.06.030

Lamb K. E., Johnson B. L. 2004. Seed-size and seeding depth influence on canola emergence and performance in the Northern Great Plains. Agronomy Journal, 96 (2): 454-461 http://dx.doi.org/10.2134/agronj2004.0454

Maselli F., Moriondo M., Angeli L., Fibbi L., Bindi M. 2011. Estimation of wheat production by the integration of MODIS and ground data. International Journal of Remote Sensing. 32 (4): 1105-1123 http://dx.doi.org/10.1080/01431160903510799

McKee T. B., Doesken N. J., Kliest J. 1993. The relationship of drought frequency and duration to time scales. Proceedings of the $8^{\text {th }}$ conference of applied climatology. American Meteorological Society, p. 179-184

Mendham N. J., Shipway P. A., Scott R. K. 1981. The effects of delayed sowing and weather on growth, development and yield of winter oil-seed rape (Brassica napus). Journal of Agricultural Science, 96 (2): 389-416 http://dx.doi.org/10.1017/S002185960006617X

Mogensen V. O., Jensen C. R., Mortensen G., Thage J., Koribidis J., Ahmed A. 1996. Spectral reflectance index as an indicator of drought of field grown oilseed rape (Brassica napus L.). European Journal of Agronomy. 5 (1): 125-135 http://dx.doi.org/10.1016/S1161-0301(96)02016-3 
Mogensen V. O., Jensen C. R., Poulsen H., Mortensen G., Thage J. H., Koribidis J. 1997. Reflectance index for early determination of water stress. Acta Horticulturae, 449: 44-49

Motohka T., Nasahara K. N., Murakami K., Nagai S. 2011. Evaluation of sub-pixel cloud noises on MODIS daily spectral indices based on in situ measurements. Remote Sensing. 3 (8): 1644-1662 http://dx.doi.org/10.3390/rs3081644

Nwafor O. M. I. 2004. Emission characteristics of diesel engine operating on rapeseed methyl ester. Renewable Energy, 29 (1): $119-129$ http://dx.doi.org/10.1016/S0960-1481(03)00133-2

Park S. 2013. Cloud and cloud shadow effects on the MODIS vegetation index composites of the Korean Peninsula. International Journal of Remote Sensing, 34 (4): 1234-1247 http://dx.doi.org/10.1080/01431161.2012.720043

Paustian K., Andren O., Janzen H. H., Lal R., Smith P., Tian G., Tiessen H., Van Noordwijk M., Woomer P. L. 1997. Agricultural soils as a sink to mitigate $\mathrm{CO}_{2}$ emissions. Soil Use and Management. 13: 230-244 http://dx.doi.org/10.1111/j.1475-2743.1997.tb00594.x

Peng D.-L., Huang J.-F., Huete A. R., Yang T.-M., Gao P., Chen Y.-C., Chen H., Li J., Liu Z.-Y. 2010. Spatial and seasonal characterization of net primary productivity and climate variables in southeastern China using MODIS data. Journal of Zhejiang University, Science B, 11 (4): 275-285 http://dx.doi.org/10.1631/jzus.B0910501

Peterson C. L., Hustrulid T. 1998. Carbon cycle for rapeseed oil biodiesel fuels. Biomass and Bioenergy. 14 (2): 91-101 http://dx.doi.org/10.1016/S0961-9534(97)10028-9

Piekarczyk J., Wójtowicz M., Wójtowicz A. 2006. Estimation of agronomic parameters of winter oilseed rape field reflectance data. Acta Agrophysica, 8 (1): 205-218

Pospišil M., Brčić M., Husnjak S. 2011. Suitability of soil and climate for oilseed rape production in the Republic of Croatia. Agriculturae Conspectus Scientificus, 76 (1): 35-39
Rao M. S. S., Mendham N. J. 1991. Comparison of chinoli (Brassica campestris subsp. oleifera $\times$ subsp. chinensis) and $B$. napus oilseed rape using different growth regulators, plant population densities and irrigation treatments. Journal of Agricultural Science. 117 (2): 177-187 http://dx.doi.org/10.1017/S0021859600065266

Rao S. C., Dao T. H. 1987. Soil water effects on low-temperature seedling emergence of five Brassica cultivars. Agronomv Journal. 79 (3): 517-519 http://dx.doi.org/10.2134/agronj $1987.00021962007900030023 x$

Rizzi R., Rudoife B. F. T., Shimabukuro Y. E., Doraiswamy P. C. 2006. Assessment of MODIS LAI retrievals over soybean crop in Southern Brazil. International Journal of Remote Sensing. 27 (19): 4091-4100 http://dx.doi.org/10.1080/01431160600851850

Russo V. M., Bruton B. D., Sams C. E. 2010. Classification of temperature response in germination of Brassicas. Industrial Crops and Products. 31 (1): 48-51 http://dx.doi.org/10.1016/j.indcrop.2009.08.007

Sahinler S., Topuz D. 2007. Bootstrap and jackknife resampling algorithms for estimation of regression parameters. Journal of Applied Quantitative Methods, 2 (2): 188-199

Sidlauskas G., Bernotas S. 2003. Some factors affecting seed yield of spring oilseed rape (Brassica napus L.). Agronomy Research, 1 (2): 229-243

Vergé X. P. C., De Kimpe C., Desjardins R. L. 2007. Agricultural production, greenhouse gas emissions and mitigation potential. Agricultural and Forest Meteorology, 142 (2-4): 255-269 http://dx.doi.org/10.1016/j.agrformet.2006.06.011

Viña A. 2012. Evaluating vegetation indices for assessing productivity along a tropical rain forest chronosequence in Western Amazonia. Israel Journal of Plant Sciences, 60 (1-2): 77-83

Xiao X., Boles S., Liu J., Zhuang D., Frolking S., Li C., Salas W., Moore B. 2005. Mapping paddy rice agriculture in southern China using multi-temporal MODIS images. Remote Sensing of Environment, 95 (4): 480-492 http://dx.doi.org/10.1016/j.rse.2004.12.009

ISSN 1392-3196 / e-ISSN 2335-8947

Zemdirbyste-Agriculture, vol. 101, No. 4 (2014), p. 445-452

DOI $10.13080 /$ z-a.2014.101.057

\title{
Palydovinio stebėjimo MODIS duomenų panaudojimas, vertinant žieminių rapsų augimą ir vystymąsi
}

\author{
K. Bartoszek \\ Liublino gyvybės mokslų universitetas, Lenkija
}

\begin{abstract}
Santrauka
Nuotolinis stebėjimas iš palydovo leidžia vienu metu nustatyti augalų vegetacijos būklę nutolusiuose plotuose. Straipsnyje vertinami palydovo duomenys, gauti iš vidutinio raiškos vaizdo spektroradiometro (MODIS), siekiant nustatyti žieminių rapsų augimą ir vystymąsi Centrinès Europos klimato sąlygomis. Tyrimas paremtas penkiụ vegetacijos rodikliu - vegetacijos indekso normalizuoto skirtumo, padidinto vegetacijos indekso, lapu ploto indekso, fotosintetiškai aktyvios spinduliuotés frakcijos ir bendrosios pirminès produkcijos - vertemis ir apima 2000-2012 m. laikotarpi, taip pat ir rapsų augalų aukščio matavimą prieš žiemojimą bei po žydejjimo ir žydèjimo bei brandos pradžios rodiklius. Mažos standartiniu nuokrypiu iverčiu paklaidos buvo nustatytos modeliuose tarp augalų aukščio prieš žiemojimą ( $<6 \mathrm{~cm})$ ir žydèjimo pradžios ( $<3$ dienos). Siekiant prognozuoti šias dvi žieminiu rapsų savybes, tai leistų taikyti vegetacijos rodiklius iš laikotarpio prieš matavimą ir lauko stebejimų duomenis. Nebuvo nustatyta esminè koreliacija tarp augalu aukščio po žydejjimo ir brandos pradžios. Oro sąlygos turèjo didelès įtakos žieminių rapsų augimui ir vystymuisi; tai atskleidè ir kitos vegetacijos rodiklių vertès.
\end{abstract}

Reikšminiai žodžiai: augimo tarpsniai, vegetacijos rodikliai, palydovinis stebejjimas, Rytų Lenkija, žieminiai rapsai. 